\title{
mssaico
}

\section{Algumas Estórias} Esquecidas Pela

\section{História: gênese intelectual,}

relações com 0

poder $\mathbf{e}$

esquecimentos na

Trajetória de Luís

Da Câmara

Cascudo

\author{
Carlos Magno dos \\ Santos Souto ${ }^{1}$
}

\section{Resumo:}

Neste artigo procuramos analisar algumas questões referentes à formação intelectual do folclorista potiguar Luís da Câmara Cascudo que tendem a ser esquecidas por alguns estudiosos de sua vida e obra, como por exemplo, suas relações com o poder político e sua participação no movimento integralista brasileiro, revelando algumas de suas facetas menos conhecidas. Com este intuito, nos debruçamos sobre parte do vasto material produzido sobre o autor, composto por biografias, autobiografias, crônicas, correspondências etc., tentando realçar exatamente $o$ que foi escamoteado nestes escritos. Daí emerge um intelectual enredado na teia do poder e que constrói sua biografia esquecendo determinados fatos.

Palavras-chave: História Intelectual - Luís da Câmara Cascudo - Integralismo - Biografia

\section{Resumén:}

En este artículo se reflexiona sobre algunas cuestiones relativas a la formación intelectual de lo folclorista potiguar Luís da Câmara Cascudo que tienden a ser pasados por alto por algunos estudiosos de su vida y obra, por ejemplo, sus relaciones con el poder político y su participación en el movimiento integralista de Brasil, que revela algunas de sus facetas menos conocidas. Con esto en mente, nos centramos en la parte del vasto material producido sobre el autor, que consiste en biografías, autobiografías, ensayos, cartas, etc., tratando de enfatizar exactamente lo que estaba oculto en estos escritos. Surge de un intelectual capturado en el red de el poder y produce su biografía olvidar ciertos hechos. 


\section{Introdução}

Luís da Câmara Cascudo constituiu, na história intelectual brasileira, um sujeito do conhecimento multifacetado. Sua longa trajetória pelo mundo das letras caracterizou-se sempre por uma espécie de onipresença nos mais variados campos do saber. $O$ horizonte de suas pesquisas era marcado pela amplitude, que conferia uma aura de grandeza a sua obra como um todo. Sempre procurou cultivar a imagem do erudito, aquele que possuía uma instrução variada, haurida, sobretudo, por longas horas de leituras e pesquisas. Não é à toa que as biografias que foram escritas sobre ele aludem, com freqüência, a suas múltiplas facetas de professor, jornalista, advogado, memorialista, critico literário, biógrafo, poeta, e também historiador, embora tenha se destacado na história cultural brasileira principalmente como folclorista e etnógrafo.

Apesar da diversidade de seus interesses intelectuais e da pluralidade dos objetos estudados, Cascudo alçou-se ao lugar de destaque (que ocupou ainda em vida e que continua a ocupar depois de morto), no cenário brasileiro, através da extensa produção e metódica pesquisa que desenvolveu nas áreas do folclore e da etnografia. Foi, sem dúvida, como estudioso da cultura e das tradições populares que obteve o reconhecimento (nacional e internacional), pelo qual ansiava. Seu status de profundo conhecedor da "cultura popular nordestina", objeto de poder-saber que ele próprio ajudou a criar, o tornou merecedor do prestígio que receberia da posteridade.

Atualmente Câmara Cascudo constitui um monumento da história intelectual brasileira. Um monumento erigido com discursos que, por um lado, enfatizam aspectos como a sua prolífica carreira de escritor (cerca de 150 livros publicados, além de incontáveis crônicas na imprensa natalense), seu pioneirismo no estudo das tradições populares e do folclore e sua profunda erudição e amor pelas letras; enquanto, por outro, omitem fatos igualmente importantes para a compreensão do sujeito Luís da Câmara Cascudo, tais como, a próxima relação que manteve, ao logo de toda a sua vida, com o poder público e a ativa participação que teve no Movimento Integralista Brasileiro, na década de 1930.

Ao pesquisar a vida e obra de Cascudo percebe-se, não sem certas dificuldades, que a construção feita sobre este ilustre personagem da História, por biografias, autobiografias, livros de memórias, etc., privilegia a linearidade e a falta de conflitos, escamoteando a fragmentação e a contradição que caracterizam a existência humana.

Portanto, neste artigo, buscamos analisar alguns pontos da trajetória de Luís da Câmara Cascudo obliterados pela maioria de seus estudiosos e biógrafos. Nossa intenção é tentar preencher algumas lacunas que Cascudo deixou na prospecção que fez de seu passado e que a produção de sua memória continua a esconder, as quais são fundamentais para traçar o perfil do folclorista enquanto intelectual. Neste sentido, afigurou-se de fundamental importância investigar, sucintamente, a produção da biografia deste autor e as relações que manteve com o poder, além de revelar uma das facetas mais secretas de Cascudo, seu papel enquanto Chefe provincial da AIB em Natal nos anos 1930. Enfim, ao longo do artigo tentamos entender por que o autor, ao longo de sua vida, silenciou sobre tais fatos. 


\title{
Um intelectual nascido da doença e da solidão
}

Luís da Câmara Cascudo, como muitos outros intelectuais de sua geração, tem suas raízes vinculadas às antigas elites do Norte do país. Em alguns de seus textos autobiográficos podemos perceber o orgulho com que se referia à antiga família Cascudo, originária do interior do Rio Grande do Norte e que se constituía em uma poderosa oligarquia local. Seu avô Antônio Justino de Oliveira, apelidado Cascudo pela intransigente devoção ao partido conservador, é apresentado como a figura forte e viril do patriarca. Ele viveu os tempos áureos e opulentos do auge da produção agrícola e pecuária do Norte, anos em que o poder de tais homens era praticamente ilimitado, época em que as grandes casas dos senhores do campo refletiam seu prestígio e sucesso. Câmara Cascudo alude com grande nostalgia aos dias de glória do avô, lembrando, com uma pitada de humor, a arrogância e o poder que emanavam dele:

\begin{abstract}
“Meu avô paterno Antônio Justino de Oliveira (1829 - 1926) ao receber uma multa trabalhando o animal na calçada residencial, não discutiu, está aí a multa de hoje, e pago também a outra, porque amanhã passarei por aqui e o cavalo vai subir a calçada de novo... E deu dispora pela estrada." ${ }^{2}$
\end{abstract}

No entanto, o raiar do novo século não trazia bons augúrios para as tradicionais camadas dirigentes nortistas. O poder político-econômico, que se perpetuava há séculos e que parecia inextinguível, começa a ruir. $O$ incipiente desenvolvimento urbano-industrial, que no campo se faria sentir pela emergência das usinas em substituição aos engenhos; a queda na exportação dos produtos agrícolas, sobretudo em virtude crise de 1929 que prejudicou a produção e a venda do principal produto da região, o açúcar; e o aumento da produção bovina no Sudeste, entre outros fatores, contribuiriam sobremaneira para o declínio das elites do Norte.

Muitos dos herdeiros das decadentes oligarquias rurais da região deslocam-se para as cidades, na busca por restabelecer os antigos privilégios de que desfrutavam. As condições econômicas desfavoráveis os levam a ingressar em diversas carreiras, entre as quais se destacam o comércio, a política e o ofício intelectual. Através do pouco prestígio que lhes restava, alguns se aliam com membros dos grupos dirigentes locais e conseguem empregos públicos.

A família Cascudo também sofreria as conseqüências deste contexto de decadência. Impossibilitado, em virtude da crise da produção agrícola, de exercer uma atividade rural, Francisco Cascudo, pai do folclorista, torna-se um dos chefes da política local em Caicó,

\footnotetext{
${ }^{2}$ CASCUDO, Luís da Câmara. O Tempo e Eu (Confidências e Proposições). Natal, Imprensa Universitária, 1968. p. 129.
} 

poder e esquecimentos na Trajetória de Luís Da Câmara Cascudo

cidade interiorana. Algum tempo depois, ainda desfrutando da influência que conseguira na política, migra para a capital do estado onde se torna alferes do Batalhão de Segurança, cargo que assegurou a ele a patente de coronel que o acompanhou pelo resto de sua vida.

“Meu pai Francisco Cascudo nasceu na vila de Campo Grande, o chefe político local Luís Pereira Tito Jacome (1835-1906) levou para Natal, recomendando-o ao governador Pedro Velho e meu pai prestou juramento como Alferes do batalhão de segurança em 13 de julho de $1892 .{ }^{\prime 3}$

Em 1900, na cidade do Natal, o coronel Cascudo envereda pelo rumo dos negócios, comprando uma loja de ferramentas e miudezas. Logo o investimento se mostraria lucrativo, e o homem que, segundo o folclorista, pertencia à "aristocracia rural", tornou-se um afortunado comerciante, adaptado à ordem capitalista. Este foi um período de prosperidade financeira para a família, e o coronel Cascudo aproveitou para consolidar a sua imagem de homem influente e respeitado. Criou bispado, orfanato, asilo de mendigos, uma companhia de bombeiros; construiu estradas de automóveis para o interior; ajudou aos retirantes da seca.

\begin{abstract}
"Alto, robusto, de proporções harmoniosas quando maço, pele fia e clara, fisionomia tranqüila de energia e mando avivado pelo fulgor imperioso dos olhos azuis (...) Maravilhoso atirador de revolver, age como um gato-do-mato, mãos e pés de linhas impecáveis. A comprovada coragem pessoal era famosa e lembrada na memória dos sertões jamais provou bebidas alcoólicas."

"Durante mais de vinte anos todas as iniciativas úteis oficiais ou particulares, tiveram em Natal a colaboração decisiva do Coronel Cascudo." ${ }^{4}$
\end{abstract}

Em uma Natal que ainda não sofrera as fissuras provocadas pelo advento da modernidade urbana, ele, aproveitando a ventura nos negócios, se consolida como uma liderança. Mesmo que não desfrute do mesmo poder que seus antepassados haviam conseguido no passado, o coronel Cascudo ainda consegue reproduzir, parcialmente, os códigos sociais de seu pai. Conserva a energia do poder de mando, o porte elegante, a virilidade, a coragem e determinação dos patriarcas rurais. Na cidade antiga, onde as hierarquias e tradições assumiam grande importância social, ele conseguia ser tratado com distinção e respeito.

É neste período áureo da família Cascudo que o menino Luís é criado. Teve dois

\footnotetext{
${ }^{3}$ CASCUDO, Luís da Câmara. O Tempo e Eu (Confidências e Proposições). Natal, Imprensa Universitária, 1968. p. 35.

${ }^{4}$ Idem. p. $34-40$.
} 
irmãos nascidos mortos, por isso desde a idade mais tenra foi cercado de inúmeros cuidados. Nasceu sob o signo da doença, marca que o acompanharia por toda vida e que o levaria, muitas décadas mais tarde, a escrever o "Manual do Doente Aprendiz".

"Fui menino magro, pálido, enfermiço. Cercado de dietas e restrições clínicas. Proibiram-me movimentação na lúdica infantil. Não corria, não saltava, não brigava. Nunca pisei em areia nem andei descalço. Jamais subi em uma árvore. Cuidado com fruta quente, sereno, vento encanado. Brincava com meninas. Um quarto cheio de brinquedos para exercício secundário. Aprendi a ler quase sozinho aos seis anos, graças ao tico-tico, proeza de Chiquinho e Jagunço. ${ }^{5 \prime}$

De acordo com Albuquerque Junior (2006: 03), Luís da Câmara Cascudo construiu sua biografia "de erudito, de homem voltado para os livros e as letras a partir do tema fundador da doença" ${ }^{6}$. À criança impedida de compartilhar o cotidiano de um menino normal, em virtude dos problemas de saúde, restava o mundo encantado dos livros, presenteados aos montes por pais e amigos, e as histórias encantadas contadas por Benvenuta de Araújo, sua ama de criação. Portanto, quando muito depois o notório folclorista escreve e fala sobre a sua escolha pela carreira de intelectual, ele procura justificar sua aptidão para o mundo das letras como uma conseqüência natural de sua meninice enferma e cercada de livros e estórias. Ele procura naturalizar sua escolha profissional, como se esta tivesse, imperiosamente, se imposto a sua vida.

Também o caráter solitário de sua infância de menino doente e isolado é utilizado na construção da biografia do "homem que devotou sua vida ao conhecimento de seu povo e de suas tradições". O hábito solitário da pesquisa nos arquivos, das intermináveis leituras durante a madrugada, trancado em seu escritório, das infindáveis horas sentado frente à máquina de escrever, produzindo um livro, Cascudo adquiriu na idade pueril.

"Tive uma meninice isolada e doente. Cercado de brinquedos mais sem companheiros de folias. Não possui amigos de infância. Meus mais antigos amigos datam dos cursos preparatórios restando raros".

Segundo a construção que faz de si próprio, e que podemos vislumbrar em livros de memórias como "O tempo e Eu" e "Pequeno Manual do Doente Aprendiz", a doença constitui o ventre solitário em que foi gerado o erudito Câmara Cascudo, "sabedor de todas as coisas do campo e da cidade". A enfermidade e a solidão o teriam conduzido,

\footnotetext{
${ }^{5}$ CASCUDO, Luís da Câmara. O Tempo e Eu (Confidências e Proposições). Natal, Imprensa Universitária, 1968. p. 44.

${ }^{6}$ ALBUQUERQUE JUNIOR, Durval Muniz de. A Escrita como Remédio: erudição, doença e masculinidade no Nordeste do começo do século XX.
} 
precocemente, pelos caminhos da leitura e da escrita. Dessa forma, a doença constitui, de acordo com suas palavras, um momento de reflexão sobre si mesmo; representa a oportunidade do auto-encontro. É ela, juntamente com a solidão que a acompanha, que irão transformar o menino Cascudo no pequeno prodígio, que impressionava até aos mais refinados amigos de seus pais com suas demonstrações de inteligência.

"A doença é um processo de análise, uma oportunidade para o autoencontro, a intimidade reveladora da própria personalidade, estar realmente consigo, entender-se, pesquisar-se. Função ideal como alter ego, disperso na diversidade das preocupações centrífugas. A moléstia nos reaproxima, restituindo-nos a unidade psicológica da nossa meninice, quando estabelecíamos a entidade total, na naturalidade, no milagre da conversa dialogal, falando sozinhos com nós mesmos" ${ }^{7}$

Sua intenção, em fragmentos autobiográficos como este, é tornar natural uma escolha que de modo nenhum é aleatória, mas que pode ser historicamente situada no contexto do declínio das elites rurais do espaço que viria a ser conhecido como Nordeste. A carreira intelectual que veio a seguir não seria uma conseqüência normal de sua infância enferma. Embora sua escrita tente apresentá-la como uma condição pré-determinada desde o nascimento, ela representa antes uma impossibilidade de reproduzir os códigos sociais familiares. Cascudo não herdaria as características que tanto admirava no avô, e que o pai conseguira parcialmente atualizar, como o poder de mando, a força e virilidade patriarcais e a própria condição de homem poderoso.

Embora nascido no seio de uma família ainda rica (é importante lembrar que o pai do folclorista, apesar de membro da "aristocracia rural", conseguiu progredir financeiramente através do comércio, uma atividade urbana), Cascudo não teria fortuna garantida pelo resto da vida. Os reveses da economia capitalista acabariam levando à falência o Coronel Francisco. A carreira intelectual, neste contexto, assume mais uma função de luta pela subsistência e meio de restituir, ao menos parcialmente, o prestígio perdido da família, do que o atributo de "dom natural".

A boa condição econômica de seu pai durante os anos de sua meninice garantiu ao jovem Cascudo a oportunidade do ensino, que na época, em uma cidade provinciana, constituía um privilégio ao qual poucos tinham acesso. Seus primeiros passos no campo educacional são dados com dona Totônia Cerqueira, que o inicia nos fundamentos da leitura. Após algum tempo passa a estudar no "Externato Sagrado Coração de Jesus", dirigido pelas irmãs Maria Emilia e Guilhermina Andrade, um ambiente educacional feminino. É possível que a influência do "sexo frágil" na formação do filho tenha desagradado ao Coronel Francisco Cascudo, que vinha de uma sociedade onde a masculinidade era ostentada como um adereço obrigatório pelos varões.

\footnotetext{
${ }^{7}$ CASCUDO, Luís da Câmara. Pequeno Manual do Doente Aprendiz. Natal, Imprensa Universitária, 1963. p. 77.
} 
O menino Luís passa então a ter aulas particulares na chácara do Tirol com o professor Francisco Ivo Cavalcanti, que se desdobrava no ensino de várias disciplinas. Segundo seus biógrafos, já nesta época Cascudo demonstrava enorme aptidão para o mundo das letras e impressionava seu mestre com sua perspicácia. Conta-se que foi neste período que adquiriu o hábito, que o acompanharia ao longo de sua vida, de passar suas noites lendo incansavelmente. Quando já havia esgotado todas as possibilidades com o professor particular, aprendendo tudo o que este tinha para Ihe ensinar, foi matriculado no Atheneu norte-riograndense onde concluiu o curso preparatório.

O período de sua infância em que esteve no sertão potiguar com os avôs seria decisivo para a sua formação como folclorista e pesquisador das tradições e costumes do povo, e este primeiro contato com o campo marca muitos dos seus prefácios e biografias.

“Conheci e vivi no sertão que era das 'eras dos setecentos'. Vivi nesse meio e deliciosamente cortei macambira e xiquexique para o gado nas secas, banhei-me nos córregos no inverno, esperei a cabeça dos rios nas enchentes, desengalhei tarrafa nas pescarias dos poços, dei laços nos açudes, cacei mocós e preás nos serrotes. Subi nas esperas sob juazeiros, persegui tatus de noite com fachos e cachorros amestrados, matei ribaçã a pau e colhia-as nas arapucas. Ouvi o canto anulado da mãe da lua imóvel nas oiticicas, ouvi histórias de Trancoso, de cangaceiros, de gente rica, guerras de família, heroísmos ignorados, ferocidades imprevistas e completas." $^{8}$

É neste momento que Câmara Cascudo, menino da cidade, descobre os costumes da região, as roupas, o vocabulário, as refeições, festas, vaquejadas e todos os elementos do campo que ele nunca tivera a oportunidade de conhecer em Natal. É este campo, povoado de rezadeiras, vaqueiros, cantadores, gente simples e valente, onde todos sabem contar histórias, que vai povoar o universo de seus livros mais importantes. Contudo, não é mais a época da opulência das grandes famílias patriarcais. Cascudo conhece o campo em um momento dramático, onde um poder mantido em equilíbrio durante séculos está em franco processo de declínio.

Assim, o sertão de seus antepassados surgirá, posteriormente, em suas obras, sempre perseguido pelo signo da morte. Suas tradições e personagens serão sempre anunciados como estando às portas do desaparecimento. O medo da morte, que o marcara desde o início de sua vida se estenderá à abordagem de seus objetos. A cidade antiga será descrita em suas crônicas como uma realidade arrasada pelo passar dos anos e pela invasão dos valores e maquinarias modernos, a cultura do povo, da qual seria um dos maiores intérpretes, é vista como um moribundo as vias do desaparecimento eminente.

\footnotetext{
${ }^{8}$ CASCUDO, Luís da Câmara. Vaqueiros e Cantadores: folclore poético do sertão de Pernambuco, Paraíba, Rio Grande do Norte e Ceará. Rio de Janeiro, Ediouro, 2000. p. 08.
} 


\section{Relações com o poder}

Em 1914 o coronel Francisco Cascudo, ainda gozando de prosperidade financeira, funda com seus próprios recursos o jornal $A$ Imprensa, para concretizar o sonho do filho de ser escritor. É lá que o folclorista publica a primeira das muitas crônicas que escreveria pelos anos afora. Em sua primeira coluna, denominada Bric-à-Brac, abordava assuntos variados mas se concentrava, sobretudo, nas pequenas críticas literárias dos livros que lia, tratando tanto de autores nacionais quanto internacionais.

O jornal ficaria conhecido pela forte determinação de seu patrono, que o manteria funcionando com seus próprios recursos por alguns anos, e por constituir uma espécie de laboratório para muitos jovens, que mais tarde viriam a se destacar entre a intelectualidade da cidade do Natal. Para Cascudo A Imprensa consistiria em um grande aprendizado, lá ele pôde desenvolver seu estilo e aprimorar a escrita de um gênero literário ao qual se dedicaria ao longo de toda a sua carreira, a crônica.

Alguns anos depois, em 1918, já demonstrando uma considerável maturidade intelectual, Cascudo inicia o curso superior de Medicina na Bahia, deslocando-se posteriormente para o Rio de Janeiro. Apesar das várias evidências de que a carreira de escritor seria a escolha mais acertada, não é de admirar que tenha enveredado pelo ramo da ciência médica. Neste período, os filhos das famílias mais abastadas da região optavam pelo curso de Medicina ou pelo bacharelado na Faculdade de Direito do Recife.

"Fui pra medicina. Filho único de pai rico, queria ter um laboratório de pesquisas e, nesse tempo, não havia curso de laboratório. Tínhamos que nos formar em Medicina. Meu pai empobreceu e eu ia sendo o pior médico do mundo. Abandonei o curso, embora me dedicando a Anatomia e Fisiologia, com presenças tão poderosas que eu ainda considero os médicos muito mais colegas do que os bacharéis." ${ }^{9}$

O sonho de se tornar médico, que certamente lhe traria prestígio e status social, é interrompido de forma brusca em virtude da falência paterna. A crise financeira familiar, que seria decisiva para que Cascudo viesse a assumir os ofícios de professor, escritor e intelectual, levou-o a abandonar o curso de Medicina.

Sobre o empobrecimento do coronel Francisco Cascudo seus livros de memórias, assim como suas biografias, não fornecem grande detalhes. A versão mais corriqueira é a de que o pai do folclorista "esbarra no declínio por ter tentado ajudar os amigos, antigos fregueses que the passaram a perna"10. Comerciante de prestígio, dono da maior loja de ferragens da cidade, $O$ Cometa, o coronel Francisco realizava negócios que envolviam grandes somas de dinheiro, inclusive negociando produtos que não pertenciam ao ramo de atuação da sua loja. Membro

\footnotetext{
9 LIMA, Diógenes da Cunha. Câmara Cascudo Um Brasileiro Feliz. Rio de Janeiro, Lidador, 1998. p. 68-69.

${ }^{10}$ OLIVEIRA, Gildson de. Câmara Cascudo Um homem Chamado Brasil. Brasília, Brasília Jurídica, 1999.
} 
de uma sociedade em que a honra constituía o bem mais valioso de um homem, exigia como única garantia de suas vendas a palavra empenhada. Em um momento onde o comércio fazia largo uso de documentos escritos, tais como duplicatas, como forma de assegurar a honestidade nos negócios, preferia fiar-se no secular costume da "palavra de homem".

Contudo, este seria seu maior erro, pois os amigos e fregueses o enganaram, deixando de saldar grandes dívidas e levando-o à falência. Mas, embora "com a fortuna abalada, nunca se queixou de nenhum freguês, tampouco ingressou com ações para débitos ou falou no assunto" ${ }^{11}$. Dessa forma, o coronel Cascudo, que na cidade antiga constituía uma das pessoas mais populares de Natal, admirado por todos, comerciante próspero, político e conselheiro do governo, benfeitor de causas sociais, na década de 1930, em uma cidade cada vez mais invadida pelos valores e signos modernos, torna-se apenas mais um rico empobrecido. $\mathrm{Na}$ Natal que passa por um vertiginoso processo de mudança, onde as tradicionais hierarquias ficam cada vez mais tênues, o homem, que no passado havia sido tão notório e influente, transforma-se em um cidadão anônimo, apenas mais um entre tantos.

Luís da Câmara Cascudo, impossibilitado de concluir o curso de Medicina, segue à trajetória intelectual da maioria dos filhos da antiga elite nortista, ingressando em 1924 na Faculdade de Direito do Recife. Quatro anos mais tarde conclui o curso, tornando-se bacharel em Direito, uma profissão que não chegaria a abraçar plenamente.

De volta a Natal consegue o cargo de professor interino de História no Atheneu norterio-grandense (assumindo em seguida a diretoria da escola), por influência de Juvenal Lamartine de Farias, na época presidente do Estado. Em 1930 é nomeado deputado estadual, contudo o mandato dura apenas dois dias, sendo destituído por ocasião da revolução de 30. É neste período que inicia a íntima relação, que se estenderia pelo resto de sua vida, com o poder e a política.

Embora sempre tenha tentado manter a imagem de homem que vivia afastado da política, sua trajetória foi repleta de relações com o poder. Para alguém que provinha de uma elite decadente, que de maneira nenhuma conseguiria manter os padrões de vida de seus antigos familiares, a proximidade com as camadas dirigentes afigurou-se como uma tábua de salvação. Cascudo se vale do prestígio que ainda restava a sua família e da tradicional amizade que sempre mantivera com os políticos e poderosos, para combater o medo da miséria e da insegurança profissional. Contudo, atribuir suas conquistas no serviço público apenas ao capital social, que sua família conseguira amealhar ao longo de décadas, seria uma grande injustiça. Sua sólida formação intelectual e escolar constituiria também uma arma fundamental na disputa por cargos e carreiras. De acordo com Miceli (2001: 79):

"Se na Primeira República o recrutamento dos intelectuais se realizava em função da rede de relações sociais que eles estavam em condições de mobilizar e as diversas tarefas de que se incumbiam estavam quase por completo a reboque das demandas privadas ou das instituições e organizações da classe dominante, a cooptação das novas categorias de

\footnotetext{
${ }^{11}$ Idem. p. 34.
} 
intelectuais continua dependente do capital de relações sociais mas passa cada vez mais a sofrer a mediação de trunfos escolares e culturais, cujo peso é tanto maior quanto mais se acentua a concorrência no interior do campo intelectual." ${ }^{12}$

Incapaz de seguir a antiga tradição familiar, Câmara Cascudo procurou apoio político e profissional, passando a obter uma parcela considerável de seu sustento através dos cargos que ocuparia no serviço público, conseguidos por meio das relações sociais que sua família estabelecera nos tempos de opulência financeira, mas também por sua refinada formação intelectual. Trabalhou na secretária do Tribunal de Justiça, foi diretor do Museu e Arquivo de Natal, Consultor Geral do Estado, quase chegou a deputado estadual, além de várias outras atribuições conseguidas graças às boas relações que sempre manteve na esfera política.

Uma experiência de dependência e agradecimento, que se traduziria em vários escritos que legitimam o lugar de poder de seus benfeitores. Escreveu livros louvando os políticos que, de alguma forma, relacionaram-se com ele, como por exemplo, Antologia de Pedro Velho e Vida de Pedro Velho, ambos sobre o ex-governador do estado, produzidos a pedido de outro político, Sylvio Pedroza, que na década de 1940 lhe agraciou com o título de Historiador da Cidade do Natal. Além destes, eram comuns as crônicas sobre a história dos grupos dirigentes locais, onde podemos encontrar um grande número de relatos de vida de políticos, a exemplo da Acta Diurna publicada em 04/09/1957, sobre o ex-deputado Olímpio Tavares:

"Foi Presidente do Banco do Natal, da Junta Comercial da Intendência Municipal, 1889-1901. Deputado Estadual nos triênios de 1898-1900, 19041906, 1907-1909, 1910-1912. Comerciante poderoso. Uma das figuras prestigiosas, influentes, dominadoras no velho Natal desaparecido."

"Viveu trinta e quatro anos como um legítimo papa-gerimun, participando da vida industrial, política, social, econômica do Rio Grande do Norte, do Império e da República."

"Lembro-me muito bem dele. Forte, robusto, corado, cara fechada, que um leve sorriso irônico dava uma breve nota acolhedora, tinha fama de mordaz, dizendo pilhérias que fugiam e feriam como dardos. Era nosso vizinho na saudosa Rua Sachet, hoje Duque de Caxias."

“Nós morávamos onde se ergue o Grande Hotel e o Coronel Olimpio Tavares onde está o Hotel Avenida. Singular destino das duas grandes casas agasalhadoras e fartas em título gratuito. São hotéis...Era, realmente, uma vocação funcional."

"Foi um dos grandes animadores para a Cidade Nova, hoje Petrópolis e Tirol, e sonhava transformar o pequenino Banco do Natal num financiador

12 MICELI, Sergio. Intelectuais à Brasileira. São Paulo, Companhia das Letras, 2001. p. 79. 
agrícola, libertando algodão e açúcar dos empréstimos escorchantes. Meu pai era muito amigo dele, recordando-lhe a verve feliz." ${ }^{13}$

Dentre as muitas figuras da sociedade potiguar que emergem de suas crônicas, várias são políticos notórios que haviam se relacionado com a família Cascudo. Desde a infância sua vida sempre fora cercada pelos poderosos, que fariam parte de seu cotidiano através dos anos. O ex-deputado Olimpio Tavares havia sido vizinho e grande amigo de seu pai. É descrito como homem distinto e empreendedor, pessoa ímpar no cenário natalense. Tendo em vista que Cascudo sempre manteve uma espécie de neutralidade política, sua intimidade com as camadas dirigentes do estado se afigura como extremamente reveladora. É inegável o tom familiar com que trata de Olímpio Tavares, e de muitas outras pessoas públicas conhecidas.

As referências constantes a homens como Pedro Velho, Alberto Maranhão, o próprio Olímpio Tavares, que encontramos em sua obra, podem ser interpretadas como uma forma de agradecimento àqueles que sempre estiveram prontos para auxiliar a família Cascudo. Suas biografias, embora não problematizem a questão, mostram como sua atividade diária era cercada pelo poder. As viagens, jantares, veraneios em companhia de generais, coronéis e políticos do estado constituíam fatos corriqueiros no seu dia-a-dia. Grandes amizades, como as que manteve com José Augusto Varela e Sylvio Piza Pedroza, são bons exemplos da sua intimidade com os poderosos.

Com a estabilidade financeira, conseguida através dos cargos no serviço público, Cascudo pôde dedicar-se com mais tranqüilidade à produção literária que o tornaria tão célebre. Uma vez que a decadência paterna não possibilitou que concentrasse suas habilidades apenas na pesquisa e na produção de artigos e livros, os empregos estaduais, obtidos tanto por meio da teia de relações sociais que mantinha com pessoas influentes da sociedade potiguar quanto por sua reconhecida capacidade intelectual, forneceram as condições econômicas necessárias para que pudesse desenvolver o talento para as letras que esboçava desde a infância. De acordo com o poeta Carlos Drummond de Andrade (1964: 558 $-559)$ :

"O emprego do Estado concede com que viver, de ordinário, sem folga, e essa é a condição ideal para bom número de espíritos: certa mediania que elimina os cuidados, porém não abre perpectivas de ócio absoluto. $O$ indivíduo tem apenas a calma necessária para refletir na mediocridade de uma vida que não conhece a fome nem o fausto (...) Cortem-se os víveres ao mesmo temperamento, e as questões de subsistência imediata, sobrelevando a quaisquer outras, igualmente the extinguirão o sopro mágico (...) o escritor-homem-comum, despido de qualquer romantismo, sujeito a distúrbios abdominais, no geral preso à vida civil pelos laços do matrimônio, cauteloso, tímido, delicado. A organização

\footnotetext{
${ }^{13}$ CASCUDO, Luís da Câmara. Olímpio Tavares. A República, 04 de setembro de 1959.
} 
burocrática situa-o, protege-o, melancoliza-o e inspira-o." ${ }^{14}$

Conquanto os empregos de professor, secretário do Tribunal de Justiça ou Consultor Geral do Estado não forneçam as condições para uma vida de fausto, eles servem perfeitamente para sanar as necessidades mais imediatas do escritor Câmara Cascudo. Desempenham uma dupla função, por um lado garantem a subsistência do folclorista e de sua família, e por outro, possibilitam que ele dê continuidade ao trabalho da pesquisa e da escrita. Seus benfeitores, sob esta perspectiva, assumem as funções de Mecenas. Eles, através de seus favores, tornam possível que o folclorista dedique uma boa parcela de seu tempo aos trabalhos no campo da cultura.

\section{Anauê}

Uma grande parte dos pesquisadores da vida e obra de Luís da Câmara Cascudo, ao tratar do tema da formação de sua subjetividade e da gênese do pensamento que o transformaria em um dos mais destacados autores de sua época, segue uma tendência bastante comum de privilegiar aspectos demasiado evidentes de sua trajetória intelectual. Seus biógrafos não cansam de apresentá-lo como "o homem que dedicou sua vida a salvar do esquecimento a cultura do povo", ou como "o brasileiro feliz", ou ainda, o "erudito professor que nunca quis afastar-se de sua província".

Seu perfil de intelectual é sempre traçado em estreita relação com o folclore, a etnografia, a história, enfim todas àquelas disciplinas nas quais atuou, e às quais dedicou longos anos de estudo. E não são apenas os que escrevem sobre Cascudo que tratam sua formação desta maneira, ele próprio em seus vários livros de memórias reforça tais imagens apresentando-se como "o provinciano incurável", "aquele que devotou sua vida às letras".

Percorrer um caminho diverso, mergulhando nas zonas de silêncio e esquivando-se dos elementos mais corriqueiros, se afigura como um procedimento bastante interessante para investigar a constituição de Luís da Câmara Cascudo enquanto autor. Nesse sentido, a observação de Robert Darton (1986: XVI -XV) acerca dos ricos indícios que encontramos camuflados no que nos parece inexplicável em nosso material de pesquisa é significativa. Para o autor de $O$ Grande Massacre dos Gatos as "áreas de opacidade e silêncio", como ele as chama, são sobremaneira importantes porque:

"Quando não conseguimos entender um provérbio, uma piada, um ritual ou um poema, temos a certeza que encontramos algo. Analisando o documento onde ele é mais opaco, talvez se consiga descobrir um sistema de significados estranho. $O$ fio pode até conduzir a uma pitoresca e

\footnotetext{
${ }^{14}$ ANDRADE, Carlos Drummond de. Passeios na Ilha. In. Obra Completa. Rio de Janeiro, Aguilar, 1964. p. 658-65.
} 
maravilhosa visão de mundo. ${ }^{15}$

Com relação a Cascudo, uma área de opacidade revelada pelos documentos, que pode ser considerada fundamental para delinearmos seu perfil enquanto indivíduo e sujeito do conhecimento é a ativa atuação junto ao movimento integralista que desempenhou ao longo da década de 1930, no estado do Rio Grande do Norte. Ao acompanharmos o percurso intelectual de Cascudo nos damos conta de que o integralismo constituiu, em determinado momento de sua vida, uma ideologia que o seduziu completamente, pois de certa forma coadunava-se com sua postura política conservadora. Contudo, sua participação no movimento teve implicações muito mais duradouras, uma vez que passou a representar uma espécie de nuvem negra que pairou sempre sobre a sua vida pública.

De fato, é curioso observar o silêncio que recai sobre os discursos de seus biógrafos quando o assunto é a obscura década de 30 e o envolvimento do folclorista com os chamados camisas-verdes. Trata-se de uma lacuna que seus comentadores propositadamente esquecem (talvez no intuito de preservar ilibada a sua memória), uma espécie de segredo que todos conhecem, porém preferem deixar a margem de sua gloriosa história. O próprio Cascudo, que com evidente orgulho, gostava de escrever em seus livros de memórias sobre seu áureo passado, onde havia conquistado uma ampla erudição e notório reconhecimento, parecia querer esquecer essa fase de sua vida, pois em momento algum a menciona, nem mesmo para tentar esclarecer os motivos que o haviam levado a entrar para as fileiras do integralismo. Contudo, esse vazio tem muito para revelar acerca de sua personalidade, pois o silêncio às vezes pode ser mais contundente do que todas as palavras que possam ser escritas sobre $o$ assunto.

O Integralismo, em linhas gerais, é uma corrente do pensamento político contemporâneo, derivada dos regimes nazi-fascistas europeus, que emergiu no Brasil no início do século passado. Caracteriza-se pela sua associação à moral religiosa, pelo apelo nacionalista e, sobretudo, pela defesa da hierarquização da sociedade como forma de manter a ordem e a paz internas.

Originalmente o integralismo pregava o antiliberalismo, buscando um Estado autoritário e nacionalista. Na época de seu aparecimento, a Europa, em especial, experimentava uma espécie de integração cada vez maior da população no sistema políticosocial. Parte desse contingente, formado por trabalhadores, acabou sendo seduzido por doutrinas socialistas, comunistas ou anarquistas. Ao contrário destas correntes de pensamento, o integralismo defendia a participação popular, mas por meio dos mitos e símbolos que representavam o nacionalismo que seus partidários tanto defendiam.

Por volta de 1930 as idéias integralistas chegaram ao Brasil e tiveram ampla repercussão entre as camadas médias urbanas e intelectuais do país. Em outubro de 1932, logo após a Revolução Constitucionalista, Plínio Salgado (o Chefe Nacional, que era merecedor de grande admiração de Cascudo) e outros intelectuais fundaram em São Paulo a

\footnotetext{
15 DARNTON, Robert: “Apresentação”. IN: O grande massacre dos gatos. Rio de Janeiro: Graal, 1986. pp. XIV e $\mathrm{XV}$.
} 

poder e esquecimentos na Trajetória de Luís Da Câmara Cascudo

Ação Integralista Brasileira (AIB). O ideário do movimento, com relativa rapidez, conquistou membros nos variados recantos do país, muitos dos quais já eram, ou viriam a ser, homens de grande reconhecimento no cenário nacional, entre os quais figuravam Helio Viana, José Lins do Rego, Álvaro Lins, Vinicius de Morais, além do próprio Luis da Câmara Cascudo.

A ênfase maior do Integralismo no Brasil se concentrava na tomada de consciência do valor espiritual da nação, assentado em princípios unificadores: "Deus, Pátria e Família" era o lema do movimento. No que diz respeito às relações entre o Estado e a sociedade, negava a pluralidade dos partidos políticos e a representação individual dos cidadãos.

A Ação Integralista Brasileira tinha como inimigos declarados o liberalismo, o socialismo, o capitalismo financeiro internacional. Como movimento de inspiração totalitarista, apresentava certa face anti-semita, sobretudo, através das idéias e obras de Gustavo Barroso, que escreveu livros como Brasil Colônia de Banqueiros e Sinagoga Paulista, que apresentam um claro fundo de ideologia nazista. Além disto, o Integralismo tupiniquim apresentava outras características que o aproximava dos regimes totalitários europeus, como o culto da personalidade do Chefe Nacional, as cerimônias de adesão e os pomposos desfiles de seus participantes vestindo uniformes verdes.

O integralismo no Brasil atraiu para suas fileiras um número significativo de aderentes. O recrutamento dos dirigentes nacionais e regionais se fez, sobretudo, entre profissionais urbanos de classe média e, não raro, entre intelectuais ligados à camadas conservadoras da sociedade, que viam no incipiente desenvolvimento do liberalismo no país e na popularização dos ideais anarquistas e comunistas entre os grupos operários, uma crescente ameaça para suas concepções políticas.

Não é uma tarefa fácil esclarecer os motivos que levaram Luís da Câmara Cascudo a se identificar com o pensamento integralista, uma vez que ele sempre manteve este assunto sob um véu de silêncio e incerteza. Contudo, não chega a ser espantoso que um intelectual profundamente enraizado em uma aristocracia decadente, enxergasse em tal movimento ideológico, uma maneira de restabelecer no presente as condições sociais e políticas de que desfrutara no passado.

Cascudo, como muitos outros intelectuais de sua geração, enxergava com grande temor a afirmação da nova ordem urbana que o processo modernizante trazia em seu esteio, à qual tinha como uma de suas principais características a dissolução das tradicionais hierarquias políticas e sociais. Dessa forma é possivel que as idéias integralistas, forjadas sobre valores tradicionais, tenham se assemelhado a uma tábua de salvação contra as agruras do tempo presente.

Se por um lado, as simpatias monárquicas e posições políticas tradicionalistas do autor, às quais nunca constituíram um grande segredo, não bastam para explicar à sua participação no movimento integralista, por outro, tais posicionamentos teóricos conservadores nos fornecem pistas muito importantes para compreendermos porque tal ideologia consistiu em uma fonte de atração tão forte para ele (a ponto de aceitar o cargo de Chefe Provincial da A.I.B. no Rio Grande do Norte). 
É necessário considerarmos que Cascudo, além de monarquista convicto na juventude, foi um fervoroso defensor das doutrinas católicas e membro de uma família tradicional e antiga da província. Dessa forma, em um momento em que a intelectualidade brasileira discutia vivamente a questão da identidade nacional, não é estranho que Cascudo tenha sido seduzido por uma corrente de pensamento político que tinha como lema "Deus, Pátria e Família". Ora, estes eram valores que faziam parte da sua própria formação subjetiva e pessoal, logo abraçar à causa integralista, mais do que uma questão de identificação de idéias, deve ter se assemelhado a um dever cívico.

Em 1933, a Ação Integralista Brasileira chegou ao Rio Grande do Norte, fundando na capital potiguar uma sede Regional e nomeando como chefe interventor Luís da Câmara Cascudo, na época talvez o mais notório defensor das idéias do movimento no Estado. Percorrendo as páginas de $A$ República neste ano e no seguinte, observamos a emergência de uma série de artigos de cunho integralista, dedicados à divulgação de sua ideologia (certamente com o intuito de recrutar novos membros), e ao detalhamento das ações na cidade. Duas colunas eram publicadas com freqüência, Ação Integralista Brasileira e Notas Integralistas. A primeira destinava-se a descrever as reuniões do movimento em Natal, esclarecendo diretrizes, marcando datas para os novos encontros, noticiando a aderência de novos membros. O caráter informativo é notório, como se pode perceber no trecho abaixo, datado de seis de julho de 1934:

\begin{abstract}
"Reúnem-se hoje, as 10:30, todos os secretários do D.P. sob a presidência do Chefe Provincial para as últimas organizações departamentais".

"Anuncia-se de modo brilhante a sessão de domingo, oito do corrente. Prestarão compromisso novos milicianos. Existe um verdadeiro entusiasmo pela A.I.B., sendo avultado o número de pedidos de inclusão que a Chefia está examinando. ${ }^{16}$
\end{abstract}

Já a coluna Notas Integralistas voltava-se para um conteúdo mais doutrinário e nacional, divulgando e explicando os argumentos integralistas a membros e simpatizantes, noticiando eventos em outros estados, apresentando datas de grande valor simbólico para os participantes, como por exemplo, o dia em que o movimento completa um ano de vida no Rio Grande do Norte:

\footnotetext{
"Passa hoje o primeiro aniversário da instalação da A.I.B. em Natal. O movimento integralista, que tantas simpatias desperta e tanta controvérsia tem provocado na explicação de sua doutrina, está no Rio Grande do Norte confiado a chefia do Dr. Luís da Câmara Cascudo que tem multiplicado seus esforços para difusão dos moços camisas verdes".
}

\footnotetext{
${ }^{16}$ A República, 06 de julho de 1934. S/A.
} 


\begin{abstract}
"Segundo a fórmula vitoriosa, os integralistas pregam a necessidade do Trabalho cada vez mais dominante, a Natureza cada vez mais dominada e o Capital cada vez mais proporcional". ${ }^{17}$
\end{abstract}

Tais artigos, que aparecem em abundancia no ano subseqüente ao da fundação da sede regional, não revelam a identidade do autor. Entretanto, parece-nos razoável imaginar que não eram escritos por Cascudo, mas por algum subordinado seu na hierarquia integralista. Note-se que o folclorista é constantemente mencionado nestes textos, mas sempre com respeito e deferência, a palavra Chefe antecedendo todas às vezes o seu nome. Além disto, estas eram notas breves e sintéticas que permitiam aos membros, que cresciam cada vez mais na cidade, acompanhar os rumos que o movimento vinha tomando.

Além destas duas colunas encontramos, no mesmo ano, um bom número de artigos, do próprio punho de Cascudo, que abordam o tema do integralismo. É interessante lembrar que as Actas Diurnas só apareceriam vários anos mais tarde, em 1938, mas já na época do entusiasmo integralista, ele colaborava com freqüência para A República. Em 1934, entre artigos sobre os mais variados assuntos, os temas ligados ao integralismo apresentam-se como uma constante em seus textos. Em tais escritos encontramos fortes críticas ao comunismo e ao liberalismo, exaltações inflamadas das virtudes da A.I.B, apologias à figura do Chefe Nacional, referências a preocupante situação do Brasil e menções à idéia de que só o Estado Integral poderia salvar o país.

É significativo que, enquanto os artigos das colunas Ação Integralista e Notas Integralistas não revelem a identidade de quem os escreveu, as matérias de Cascudo tragam sua clara assinatura. $O$ fato de todos os textos escritos por ele, que tem como tema o integralismo, serem autorais constitui um forte indicativo de seu prestígio dentro e até mesmo fora do movimento. Ter Câmara Cascudo entre os membros da Ação Integralista Brasileira era benéfico para o movimento, uma vez que a admiração que lhe era devotada seria, possivelmente, transferida para a ideologia que defendia. O autor natalense já então desfrutava de um certo reconhecimento nacional, por sua obra de etnógrafo e folclorista, e sua assinatura nos artigos relativos ao integralismo funcionava como um argumento de autoridade para as teses da A.I.B.

Em 1 10 de julho de 1934, encontramos o seguinte texto sobre a figura do Chefe Nacional Plínio Salgado:

“... me lembro dele escrevendo o Estrangeiro. la a pé para o Braz ver o emigrante rico e o judeu pobre e voltava, acampando para o café no Pignoni. Existirá ainda o Pignoni? Plínio, entre outros tipos criava Juvêncio, que nós aclamamos como o exemplo do potencial brasileiro. Juvêncio, numa cena final, estrangula um bando de papagaios de estimação por que os bichos só sabiam cantar em italiano e rogar pragas em sírio. Nem uma

\footnotetext{
${ }^{17}$ A República, 14 de julho de 1934. S/A.
} 
palavra em brasileiro. Mas não é disto que se trata."

"Também não será, senhores burgueses, capitalistas ilustres, comunistas simpatizantes, indiferentes soberbos, ignorantes doutores, insultadores de Deus, da Pátria e da Família, invertidores de todas as ordens morais e físicas, do INTEGRALISMO que falarei. Não quero perguntar rumos doutrinários nem dialéticas argumentadoras, pró e contra. $\mathrm{O}$ que pergunto é o segredo de Plínio Salgado..."

"Porque, francamente, dizem-me uns, ele não tem presença. Dá vontade de lembrar o tamanho da boneca de Nuremberg que possui Dolfuss e insinuar que Hitler não parece nada com o gigante Adamas tor. Mas, convenhamos que Plínio não tenha físico, jeitão para movimentar duzentos mil brasileiros. Não tem. Acabou-se. (...) Não tendo Plinio nem físico, nem cultura, nem voz, nem passado, (como se Mussolini, Kemal, Salazar explicassem a obra nacional pela projeção de seu pretérito) nem outros valores materiais para empolgar a grande massa, como justificarmos nós a existência de vinte e duas chefias provinciais, trinta jornais e estes 200.000 rapazes cujo número desnorteia a opinião pública, mesmo de quem não a tem?"

“Não é o livro, a palavra, o exemplo, a atitude de Plínio Salgado que nos seduziu e o elegeu perpetuamente nosso Chefe. Aquilo estava em todos nós. Plínio foi à mão forte que percutiu a rocha em cujo silencio a onda sonora dormia, inútil e parada. (...) Agora ela estourou, vasta e alta, vaga equinocial, tempestuosa e fremente, cobrindo vitoriosamente todos os cachopos das margens, pedreiras das ribas e recifes das praias..." ${ }^{18}$

Este artigo deixa transparecer todo o devotamento e entusiasmo que Cascudo dedicava à causa integralista e ao seu Chefe. Plínio Salgado na sua compreensão era um exemplo ímpar na história política brasileira. Homem "simples, paupérrimo, sem casamento rico, sem ser genial", que conseguiu se converter no "Esperado, homem oportuno, herói", através de idéias que o levaram a fundar e dirigir o que Cascudo concebia como o mais lindo e inexplicável de todos os movimentos sociais do Brasil desde 1500.

Em uma época em que muitos intelectuais procuravam repensar a realidade do país, no intuito de forjar uma nova nação e uma verdadeira identidade nacional, Plínio Salgado criava o personagem Juvêncio, o mestre-escola, cujo exemplo de civilidade chega ao extremo. Para Cascudo este personagem constitui, nas suas próprias palavras, o exemplo do potencial brasileiro. $\mathrm{O}$ ato de estrangular os papagaios de estimação que só cantavam em italiano e despejavam pragas em sírio, talvez equivalha à ação de sufocar os "pérfidos" movimentos sociais, como o anarquismo e o comunismo, que rondavam o Brasil.

No entender de Cascudo o verdadeiro brasileiro devia mirar-se em Juvêncio, o que significava vestir o uniforme verde do integralismo e combater, com as próprias mãos, os papagaios "capitalistas-ilustres", "comunistas simpatizantes", e todas as demais aves de

\footnotetext{
${ }^{18}$ CASCUDO, Luís da Câmara. “O Caso Plínio Salgado”. 1 de julho de 1934.
} 
rapina que ameaçavam com suas falácias à tríade Deus, Pátria e Família. Suas palavras talvez possam ser traduzidas pela dualidade: ou se está conosco ou se está contra nós, isto é, ou o cidadão é integralista ou é contrário a todas as ordens morais e físicas, não há meio termo. Seu pensamento, que se mostra repleto de esquecimentos, parece não lembrar que o próprio pai, em um passado não muito distante havia sido um próspero comerciante, portanto, burguês e capitalista ilustre.

Aos que não entendiam como Plínio Salgado, homem sem presença, físico, jeitão, conseguia congregar milhares de brasileiros em torno de si e de seus ideais, movimentandoos rumo ao avanço integralista, Cascudo oferece um paralelo: Mussolini, Kemal ou Salazar por acaso possuiriam tais atributos? Hitler, por acaso, assemelhava-se ao gigante mitológico Adamastor, filho da terra que se rebelou contra Zeus? A resposta, embora ele não revele, é negativa. E neste ponto, Cascudo deixa entrever uma das questões que talvez mais tenha contribuído para motivar o posterior silêncio, que sempre encobriu à sua atuação como líder integralista: a clara associação do integralismo com os regimes totalitários europeus da primeira metade do século XX.

O que Plínio Salgado teria em comum com ditadores como Mussolini, Kemal, Salazar ou mesmo Hitler? A resposta de Cascudo é que apesar de serem homens sem "físico, nem cultura, nem voz, nem passado" estavam realizando uma grandiosa "obra nacional". O ato de justificar a legitimidade da liderança de Plínio Salgado através de uma breve referência a estes nomes talvez seja extremamente revelador. É possível que estas figuras, no momento em que Cascudo escreveu tal artigo (antes que fosse revelada, com o fim da segunda grande guerra, toda a brutalidade dos regimes nazifascistas), representassem para ele, e para a maioria dos integralistas, uma espécie de modelo de líder político; homens fortes e decididos como o próprio Plínio Salgado, que apesar de suas aparências frágeis, tinham as idéias firmes e os pulsos fortes necessários para comandar uma nação.

Em outro artigo, de outubro de 1934, no qual Cascudo discute os motivos porque a A.I.B concorreria às próximas eleições, encontramos mais uma explicitação dos princípios integralistas e uma crítica mordaz aos movimentos considerados inimigos da tríade Deus, Pátria e Família:

"E o que é o Integralismo? Uma frase curta, profunda e da qual se podem tirar inúmeras conclusões, o define claramente. É um movimento destinado a salvar o Brasil da anarquia e que por isso mesmo exige de todos que a ele pertencem o juramento solene de serem fiéis a DEUS, à PÁTRIA e à FAMílIA, noções básicas da ordem social. (...) O Integralismo, portanto, é inimigo de todos quantos combatem a Religião, bem supremo da Nações, e a idéia de Deus onipotente, finalidade última da pessoa humana."

"Declara guerra sem tréguas a todos os movimentos que procuram apagar os sentimentos de Pátria, como por exemplo o comunismo, que pretende fazer desaparecer as nações, para construir um Estado universal, subordinado a Rússia, o que é inadmissível. Também combate a liberal 
democracia, que trouxe a chegada do capitalismo e os partidos políticos, que só fazem alimentar ódios, regionalismos, brigas intermináveis e prejudiciais, separando filhos de um mesmo país, da mesma província e do mesmo município."

"Comunismo, capitalismo, liberalismo, são portanto contrários aos interesses do Povo, à sua felicidade, pois criam situações de privilégios, de um lado e de miséria, de outro, para determinadas pessoas, sem se lembrarem de que TODOS têm direito à felicidade. (...) Finalmente, o integralismo defende com ardor a instituição da família, porque sabe que é da pureza do Lar, da sua segurança, que depende o futuro das Pátrias. Segurança econômica e principalmente segurança moral. Todas as medidas que procuram enfraquecer a Família têm a nossa repulsa. O Divorcio, a restrição dos nascimentos, o socialismo pedagógico, a exploração do trabalho da mãe de família fora do lar, não podem ser admitidos." ${ }^{19}$

Cascudo inicia o texto esclarecendo uma questão fundamental: o que era o integralismo. Para ele esta pergunta podia ser respondida por uma única frase. 0 integralismo seria simplesmente, o movimento dedicado a salvar o Brasil do estado caótico em que se encontrava, livrando à pátria da ameaça anárquica. Mas quem seriam os agentes desta anarquia que rondava o país? As palavras deste artigo não deixam dúvidas quanto a este ponto. No entender de Cascudo, os inimigos do Estado brasileiro e, consequentemente, do integralismo eram todos aqueles movimentos que punham em risco à tríade Deus, Pátria e Família, "noções básicas da ordem social", ou seja, comunismo, capitalismo e liberalismo. 0 combate a estes três elementos componentes da nova realidade nacional, de fato, ocupa um espaço significativo dos artigos cascudianos sobre o tema integralista.

Por meio deste artigo, vislumbramos as posições políticas de um intelectual conservador, que encara o movimento integralista como uma defesa dos valores tradicionais contra a avalanche trazida pelos novos tempos. Se ele se posiciona contra o comunismo é porque o seu sentimento nacionalista lhe adverte que este regime quer acabar com a nação brasileira, para incorporá-la ao Estado Universal, subordinado a Rússia. Sua crítica à liberal democracia, por sua vez, se justifica por esta ter trazido ao território nacional o capitalismo e os partidos políticos, que só fazem estimular a fragmentação, alimentando ódios, separando os irmãos de nacionalidade, criando brigas infindáveis.

Enfim, para Cascudo as idéias integralistas encontram legitimidade em sua defesa de Deus, da Pátria e da Família. Estes princípios, que no seu entender, estão cada vez mais ameaçados pela modernidade, constituiriam a garantia de uma sociedade feliz, esvaziada de tensões. O conservadorismo, que sempre transpareceu de sua vida pública e de sua obra, se reflete em seu apoio à ideologia integralista, em um momento em que se fazia premente a atuação intelectual na esfera política.

\footnotetext{
${ }^{19}$ CASCUDO, Luís da Câmara. "Por que a Ação Integralista Brasileira concorre às eleições de 14 de Outubro". 05 de outubro de 1934.
} 
78 Algumas Estórias Esquecidas Pela História: gênese intelectual, relações com o poder e esquecimentos na Trajetória de Luís Da Câmara Cascudo

\section{Conclusão}

Como já foi salientado anteriormente, a intimidade de Câmara Cascudo com o poder e com os poderosos, assim como sua participação junto ao movimento integralista, permanecem como algumas das lacunas entre as muitas obras que se debruçam sobre sua trajetória intelectual. É importante lembrar que o próprio autor sempre preferiu evitar tais assuntos, colocando-os a margem da construção de sua memória.

As tentativas de camuflar tais aspectos de sua vida têm muito para revelar. Se é, principalmente, através da memória que podemos nos aproximar do passado de uma existência, devemos lembrar que esta mesma memória é também construção. Isto é, rememorar o passado significar ordenar lembranças que estão intimamente ligadas ao seu sujeito. O que é lembrado, todavia, obedece a um subjetivo processo de seleção. Portanto, esquecer é um procedimento que, tanto quanto lembrar, compõe a produção memorialística.

Restaurar completamente o que foi olvidado pelo processo de produção do passado constitui uma tarefa, em grande medida, improvável. O esquecimento é parte fundamental da memória, pois consiste no contraponto de sua ação, ou seja, aquele que lembra também esquece, pois memória é também escolha. Com relação a Cascudo, o que é lembrado em sua trajetória intelectual, se sobrepõe ao que foi esquecido. É possível que para ele (enquanto esteve vivo), e para os cultores de sua memória, a rememoração de seu passado integralista significasse um choque, trazendo à tona sentimentos extremamente perturbadores, como embaraço e vergonha.

O seu próprio silêncio, assim como o de seus biógrafos, configura-se como um artefato, utilizado na batalha que foi, e ainda continua sendo travada em torno da preservação de sua memória. O passado de Cascudo é construído como um espaço calmo e destituído de tensões. Todas as possíveis nódoas que possam embotar à sua imagem de intelectual simpático, "homem do povo", são camufladas.

\section{Bibliografia}

ALBUQERQUE, Durval Muniz de. O Engenho Anti-Moderno: A Invenção do Nordeste e Outras Artes. São Paulo: Cortez, 1999.

. De Amadores a desapaixonados: eruditos e intelectuais

como distintas figuras do Conhecimento no Ocidente Contemporâneo. Barcelona, Mimeo, 2002.

A Escrita como Remédio: erudição, doença $e$ masculinidade no Nordeste do começo do século XX. 
ARRAIS, Raimundo. Crônicas de Origem: A cidade de Natal nas crônicas cascudianas dos anos 20. Natal: EDUFRN, 2005.

CASCUDO, Luís da Câmara. Civilização e Cultura. Rio de Janeiro: Itatiaia, 1983. - História da Cidade do Natal. Rio de Janeiro: Civilização Brasileira, 1980. - Na Ronda do Tempo: Diário de 1969. Natal: Imprensa Universitária, 1971. - Ontem: maginações e notas de um professor de província. Natal: Editora Universitária, 1992. . O tempo e eu: confidências e proposições. Natal: Imprensa Universitária, 1968. - Pequeno Manual do Doente Aprendiz. Natal: Imprensa

Universitária, 1963.

- Vaqueiros e Cantadores: Folclore poético do sertão de Pernambuco, Paraíba, Rio Grande do Norte e Ceará. Rio de Janeiro: Ediouro, 2000. 6.

DARNTON, Robert. O grande massacre dos gatos. Rio de Janeiro: Graal, 1986.

FOUCAULT, Michel. Microfisica do Poder. Rio de Janeiro: Graal, 1984.

GAGNEBIN, Jeanne Marie. Lembrar, Escrever, Esquecer. São Paulo: Editora 34, 2006.

GONÇALVES, José Reginaldo. A Fome e o Paladar: A Antropologia Narrativa de Luis da Câmara Cascudo. Disponível em: http:// bibliotecadigital.fgv.br/ojs/índex.php/reh/article/.../2210. Acesso em: 20 de setembro de 2011.

MICELI, Sergio. Intelectuais à Brasileira. São Paulo: Companhia das Letras, 2001.

NEVES, Margarida de Souza. Artes e Ofícios de um "Provinciano Incurável". In: Projeto História. Revista do Programa de Estudos Pós Graduados em História e do Departamento de História da PUC-SP. No. 24 Artes da História \& outras linguagens. São Paulo: PUC-SP, Junho de 2002. pp. 65 a 86.

- Viajando o Sertão. Luís da Câmara Cascudo e o Solo da 
80 Algumas Estórias Esquecidas Pela História: gênese intelectual, relações com o poder e esquecimentos na Trajetória de Luís Da Câmara Cascudo

Tradição. In: História em Cousas Miúdas. Campinas: Ed. da Unicamp, 2005. p. 237-262.

LIMA, Diógenes da Cunha. Câmara Cascudo Um Brasileiro Feliz. São Paulo: Lidador, 1998.

OLIVEIRA, Gildson de. Câmara Cascudo um Homem Chamado Brasil. Brasília: Brasília Jurídica, 1999. 